\title{
Prioritizing interventions to reduce seismic vulnerability in school facilities in Colombia
}

\author{
Miguel G. Mora, ${ }^{\text {a) }}$ Jairo A. Valcárcel, ${ }^{\text {b) }}$ Omar D. Cardona ${ }^{\text {c) }}$, Lluis G. \\ Pujades, ${ }^{\text {b) }}$ Alex H. Barbat ${ }^{\text {a) }}$ and Gabriel A. Bernal ${ }^{\text {a) }}$
}

Colombian seismic code NSR-98 establishes the requirement for the seismic vulnerability analysis and, if necessary, the strengthening of public facilities (schools). Due to the investments required by risk reduction programs, it is necessary to establish criteria for assigning priorities for the interventions. This article proposes a methodology for obtaining a Benefit-Cost Ratio (BCR) at the subnational level, by assessing the expected annual average loss of the built area of public schools and the retrofitting cost. The BCR is estimated as the difference between the estimates of the net present value for status quo and retrofitted states, these two divided by the retrofitting costs. According to the BCR, $47.3 \%$ of the total school built area of Colombia should be retrofitted where the retrofitting costs correspond to $25 \%$ of the total investment. Proposed BCR is useful for prioritizing regions in function of the feasibility of reducing the seismic vulnerability of the schools.

\section{INTRODUCTION}

In Colombia, the performance of the schools during earthquakes has highlighted the vulnerability of these facilities and the importance of the development of risk reduction programs. According to CEPAL (1999), during the earthquake of the 25 of January of 1999 , from 521 facilities, 143 (28\%) were completely damaged; 294 (56\%) were repairable and 84 (16\%) suffered minor damages. The damages affected near 4,000 classrooms, 15,000 teachers and more than 143,000 pupils. The economic value of the losses in the educational

\footnotetext{
a) Department of Structural Mechanics, Civil Engineering School, Polytechnic University of Catalonia, Building C1, Campus Norte UPC, Jordi Girona 1-3, 08034 Barcelona, Spain.

b) Department of Geotechnical Engineering and Geosciences, Civil Engineering School, Polytechnic University of Catalonia, Building D2, Campus Norte UPC, Jordi Girona 1-3, 08034 Barcelona, Spain.

c) Universidad Nacional de Colombia, Campus Palogrande. IDEA, Cra. 27 No. 64-60, Manizales, Colombia.
} 
facilities was around $1.3 \%$ of the gross production of the Departments of Colombia affected by the earthquake (departments are the second level sub-national administrative areas, like estates in EEUU).

In 1998, the National building code NSR-98 established the requirement of the seismic vulnerability analysis and, if necessary, the strengthening of public facilities, including the schools. Among the efforts made for vulnerability reduction, the Educational Secretariat of Bogotá promoted in 2004 the evaluation of the seismic vulnerability of the public schools of the city. The vulnerability of the schools was evaluated by using capacity based indexes making rough estimates of the shear and vertical loads, as well as drift based indexes, taking into account basic information of the geometry and configuration of the structural systems (Proyectos y Diseños - P\&D, 2000). Due to the high costs associated to the structural intervention and relocation of those facilities (near to $3.5 \%$ of the total expenditure in public education of the country), the most relevant and critical were considered as a priority for strengthening (Coca, 2006).
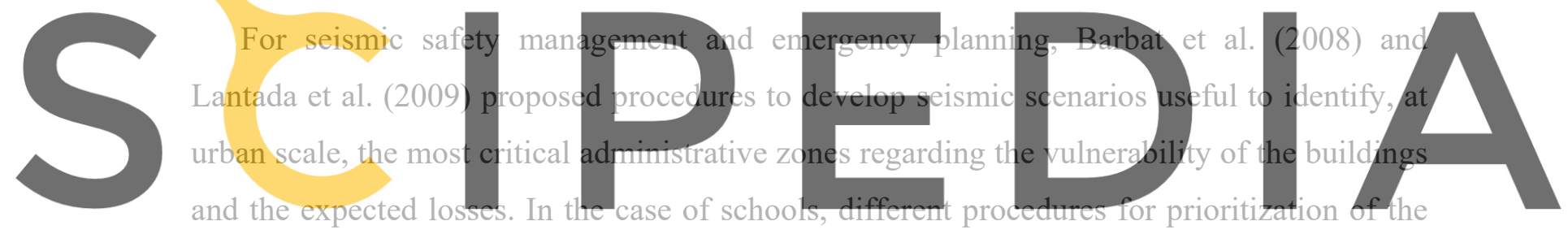

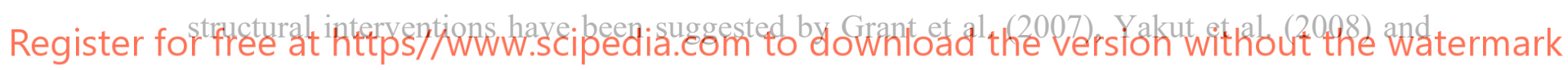
Lopez et al. (2008). In those methods, the seismic demand is associated to specific return periods, according to the seismic design requirements and to the performance objectives. For risk management purposes, it is necessary to consider that any structure is potentially exposed along its lifetime to all the possible ground motion intensities being the site characterized by specific seismic hazard curves (Hadjian, 2002). In this sense, Kappos \& Dimitrakopoulos (2008), Smyth et al., (2004a) and Smyth et al. (2004b) developed a Benefit Cost Analysis of the seismic retrofitting of residential buildings and schools, taking into account all potential harmful events.

According to Grossi (2008), risk metrics such as the Loss Exceedance Curve (LEC) and the Annual Average Loss (AAL) are useful to evaluate risk mitigation strategies for building portfolios, following a probabilistic approach. Crowley et al. (2006) propose a methodology to obtain the LEC and present examples of loss estimations at the city level, which compare the seismic risk among specific portfolios. For risk management and decision making, 
governments and international organizations may require loss assessments aggregated at national and subnational levels. In this sense, estimates of the AAL and LEC curves have been obtained for the Global Assessment Report supported by the International Strategy of Disaster Risk Reduction, ISDR (GAR, 2011).

In a benefit cost analysis of risk mitigation strategies, it is necessary to estimate the expected costs of the intervention and assign (monetary) values to a list of benefits, and summarize the feasibility or goodness of an alternative by using metrics such as the expected Net Present Value (Aven \& Kristensen, 2005). In the case of schools, a comprehensive evaluation of the benefits of risk mitigation strategies should include the expected losses in terms of the economic value of the buildings, as well as the risk to the life of the students and the disruption of the educational services. Given the difficulties to justify an acceptable value of the loss of life (May, 2007) or a target probability of failure of the schools' services, benefit cost analysis often consider consequences measurable into monetary terms and exclude others. As a complement, cost effective indices are suggested in order to solve this
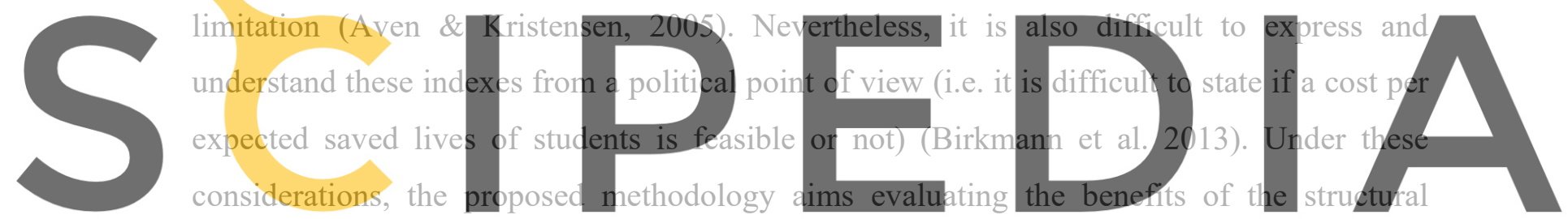

interventions in schools based on the expected damages and economic losses of buildings. In

Register for free at https//www.scipedia.com to download the version without the watermark this regard, the use of the AAL is encouraged, given that this metric allows identifying the

expected losses in buildings due to the seismic hazard of the area where they are located.

The analysis is carried out in the current case and in the case of a hypothetical structural intervention. The expected losses are estimated at municipality level, for a set of random events generated according to the seismicity of the country. For each municipality, buildings have been classified into structural typologies with specific vulnerability curves that relate, for a given ground motion intensity, the expected value of the loss and its standard deviation. By comparing the loss estimates with the expected costs of the intervention (both aggregated by departments), it is possible to obtain a benefit-cost ratio. This article presents a detailed description of the proposed methodology and results of its application at a sub national level in Colombia. At national level, for regional comparisons, this methodology has been applied in 14 countries of Latin America and the Caribbean (see Valcárcel et al., 2013). 


\section{METHODOLOGY}

\section{OVERVIEW}

In order to evaluate the feasibility of the seismic risk reduction of the buildings portfolio, the Benefit Cost Ratio, BCR, is estimated as:

$$
B C R=\frac{L_{U}-L_{R}}{C_{R}}
$$

where $L_{U}$ is the net present value of the losses due to all future earthquakes for the existing, not reinforced, case, $L_{R}$ is the net present value of the losses due to all future earthquakes for the retrofitted case and $C_{R}$ corresponds to the retrofitting costs (Mora et al., 2011). A similar BCR has been suggested by Silva et al. (2013). In the estimation of the AAL it is assumed that, in the long run, the expected losses would be equal to the sum of the AAL. In this sense, the AAL could be considered as a loss that occurs indefinitely, in perpetuity. Mora et al. (2011) determined that the expected value of $L_{R}$ and $L_{U}$ could be estimated according to the
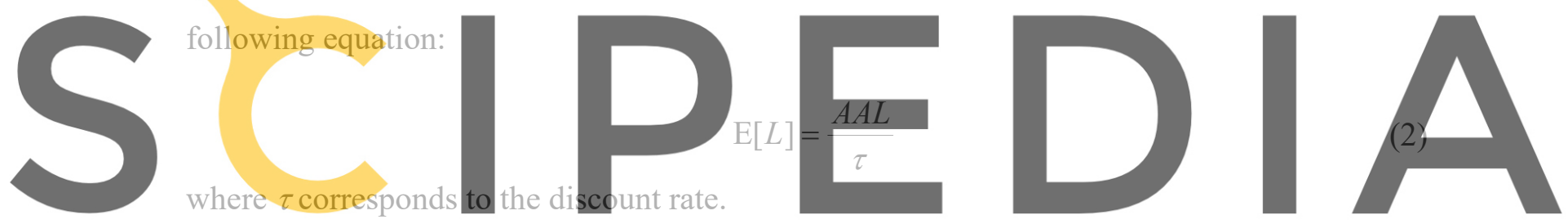

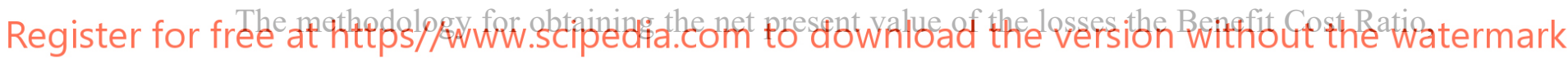

encompasses the following steps: i) seismic hazard assessment, in which a set random

seismic events are generated and the corresponding spectral accelerations at the buildings location are obtained; ii) exposure assessment, in which the buildings built area and their economic value are estimated and buildings are classified into structural typologies; iii) vulnerability assessment, in which vulnerability functions for each typology are developed; and, finally, iv) loss assessment, in which the annual average loss of the buildings portfolio in the current conditions and in the case of a hypothetical structural intervention are estimated.

\section{HAZARD: GENERATION OF A SET OF SEISMIC EVENTS}

The objective of this step is to obtain the acceleration spectra for seismic events of different return periods in firm soil. This requires i) the definition and characterization of the main seismic sources, ii) the definition of the seismicity of the sources, iii) the generation of a set of events consistent with the regional distribution of location, depth, frequency and 
magnitude of the earthquakes and iv) the evaluation of the spectral acceleration at any site of interest. This computations have been performed by using the software CRISIS 2007 Version 7.2 (Ordaz et al., 2007).

The geometry of the sources and their seismicity parameters have been defined according to the national hazard assessment study of Colombia (AIS, 2009). Based on this information, a set of seismic events of diverse magnitudes is generated through a sampling procedure, based on the recursive division of the sources' geometry. The seismicity parameters of each segment are assigned by weighting its area/length in relation to the total area/length of the source. The stochastic process of occurrence of earthquakes in each seismic source zone was modeled as a Poisson process (Egozcue et al. 1991).

Once generated the set of events, the expected spectral acceleration at any site of interest (for 5\% of critical damping) is obtained using the attenuation laws proposed by Gallego (1999) which relate magnitude, relative position source-site and spectral acceleration. This variable is approximately proportional to the lateral inertia forces induced in structures during
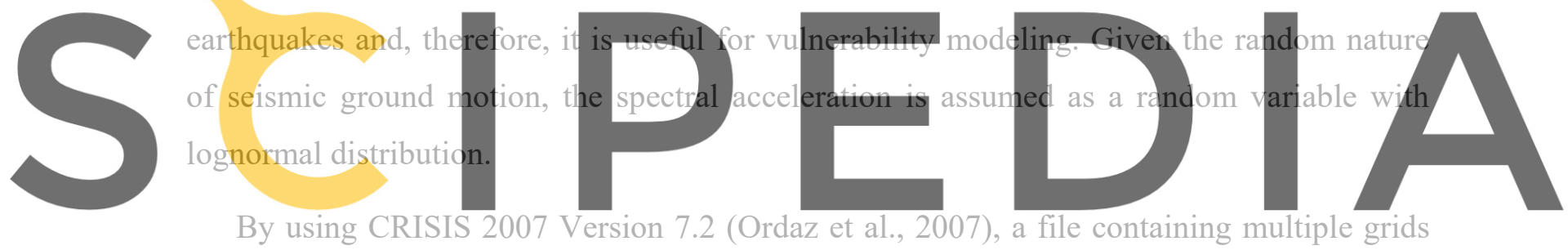

By using CRISIS 2007 Version 7.2 (Ordaz et al., 2007), a file containing multiple grids

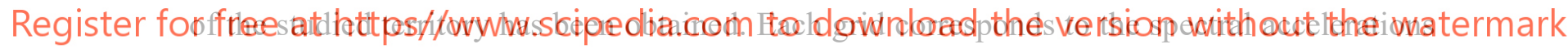

calculated for each event, the structural period and the statistical moment of the spectral acceleration (expected value and standard deviation). Those events are characterized by their magnitudes and their frequency of occurrence. The number of generated seismic events depends on the size of the sub-sources obtained through the recurrent division of the sources' geometry and the ranges of magnitudes between the minimum and maximum of each defined source. In this study, a total of 9,223 sub sources and 6 ranges of magnitude have been obtained; thus, a total of 55,338 events have been generated. In Figure 1 (a) the seismic events included in the analysis are plotted. Figure 1 (b) shows an example of the spectral accelerations estimated for a single event generated by the seismic source "Benioff intermedia" (located in the subduction zone of the Nazca plate). Figure 1(c) shows the hazard map for a return period of 500 years (AIS, 2009). 


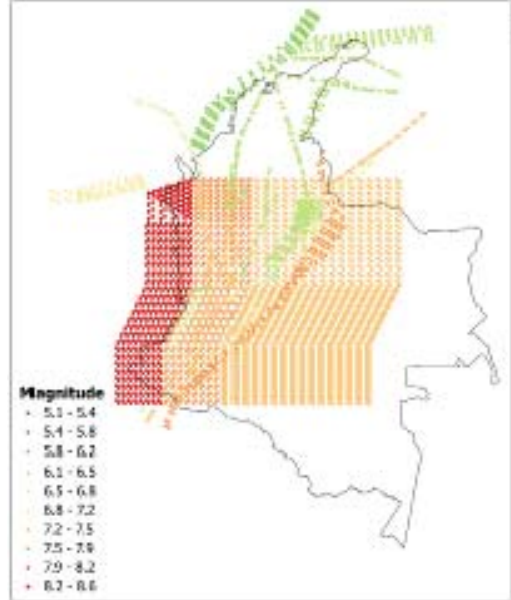

(a)

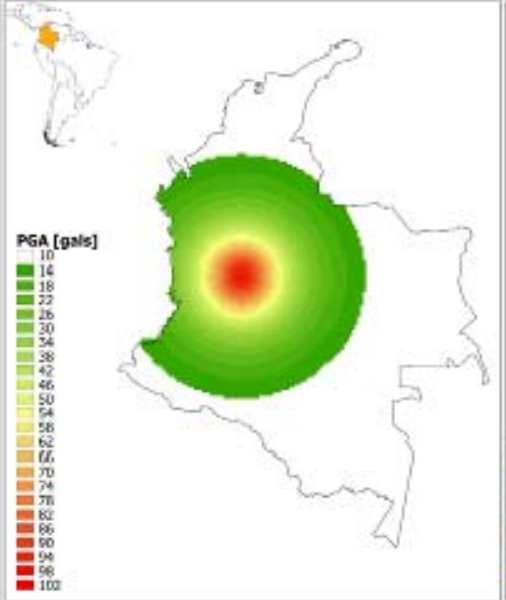

(b)

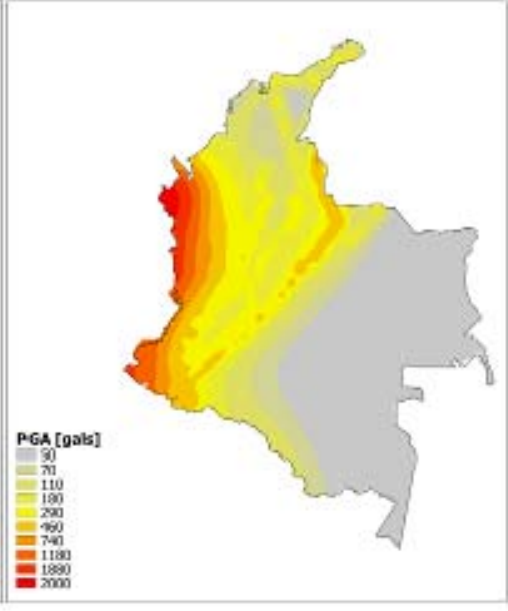

(c)

Figure 1. (a) Seismic events location included in the analysis (array of epicenters across de seismic faults); (b) Example of the spectral accelerations estimated for a single event; seismic source:

"Benioff intermedia", magnitude: Mw 7.75, depth: $\approx 100 \mathrm{~km}$. (c) Hazard map for a 500 years return period (AIS, 2009).

\section{EXPOSURE}
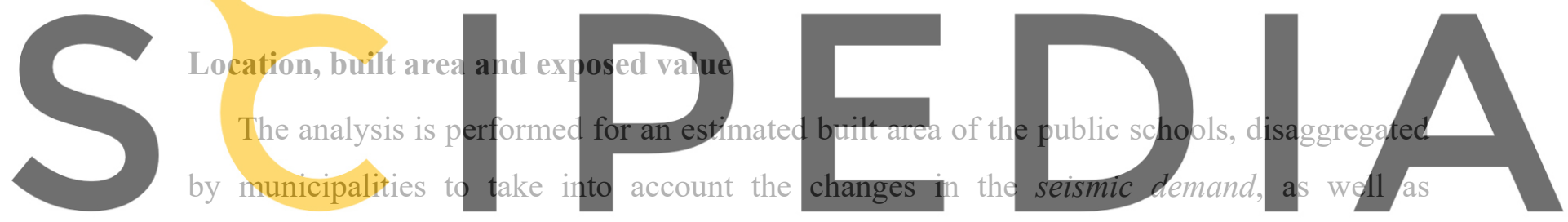

disaggregated by structural typologies to take into account the differences in the building

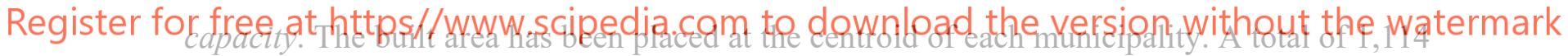

municipalities are included. For each municipality, the number of students is obtained from

the National Department of Statistics (DANE, 2008). The analysis is carried out on public schools for which the built area is estimated as a percentage of the total schools built area (public schools area plus private schools area). This percentage depends on whether the municipality is considered urban or rural, according to the ranges of population shown in Table1. These percentages have been obtained from the average number of students enrolled in urban and rural areas.

Table 1. Percentages of public school built area by ranges of population

\begin{tabular}{lccc}
\hline Complexity & Population range & $\begin{array}{c}\text { Public education (\%) } \\
\text { (World Bank, 2011) }\end{array}$ & $\mathrm{m}^{2} /$ student \\
\hline Urban & $>100,000$ & 50 & 2.51 \\
Medium & 20,000 to 100,000 & 80 & 2.15 \\
Rural & $<20,000$ & 100 & 1.79 \\
\hline
\end{tabular}

Mora - 6 
From the database of the public school buildings included in the program of vulnerability assessment in Bogotá, it was found that, in most of the schools, the built area per student is ranged between 0.9 and $2.1 \mathrm{~m}^{2}$ (SED, 2004). Also, in the Guide for Preparation of School Infrastructure Plans, the area suggested is around $2.5 \mathrm{~m}^{2}$ per student (GTC 223, 2011). Therefore we assumed a standard values for the built area per student shown in Table 1, to take into account the infrastructure complexities between urban-rural population agglomerations. In order to estimate the economic value of the buildings (replacement value), prices per $\mathrm{m}^{2}$ were obtained from the national center of statistics and from the retrofitting project of Bogotá. An average cost of 547 \$US per $\mathrm{m}^{2}$ have been selected. Table 2 summarizes the exposed values at country level.

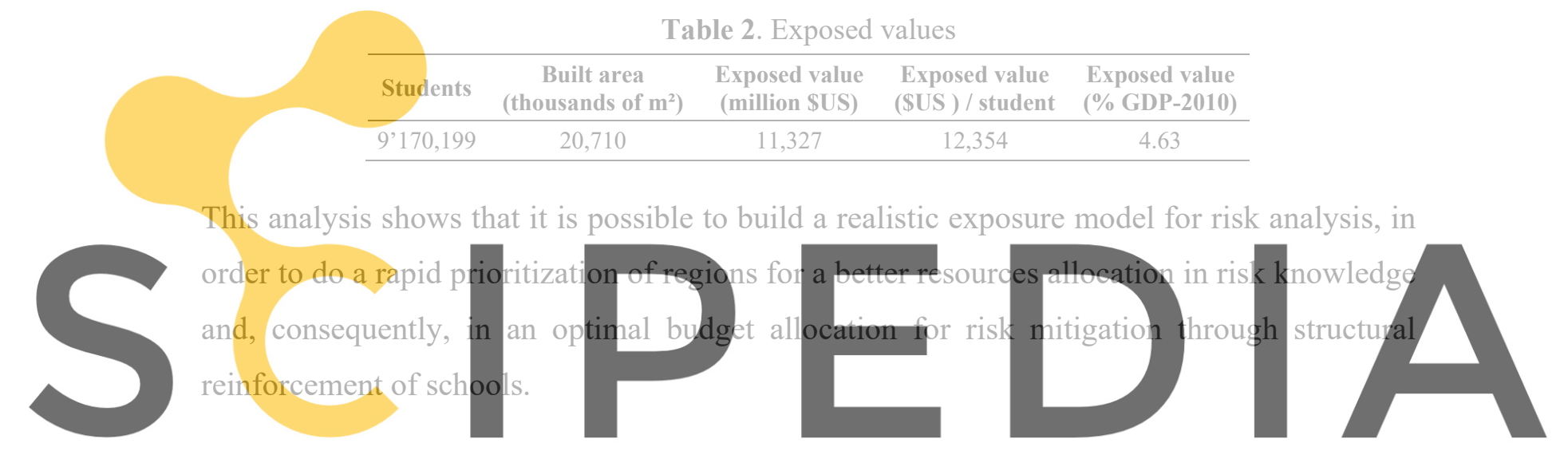

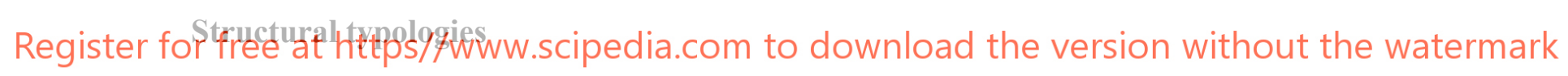

The representative structural typologies were selected according to the description of the

architectural patterns and construction techniques of the educational facilities (Maldonado, 1999). We also considered the data collected by Coca (2011) regarding the vulnerability reduction project of the schools of Bogotá. Accordingly, the most structural typologies used in schools are wood frames, unreinforced masonry, reinforced masonry and reinforced concrete frames and, typically, they are of low rise buildings, with 2 or 3 floors. Figure 2 shows the composition of the schools portfolio by structural typologies. 


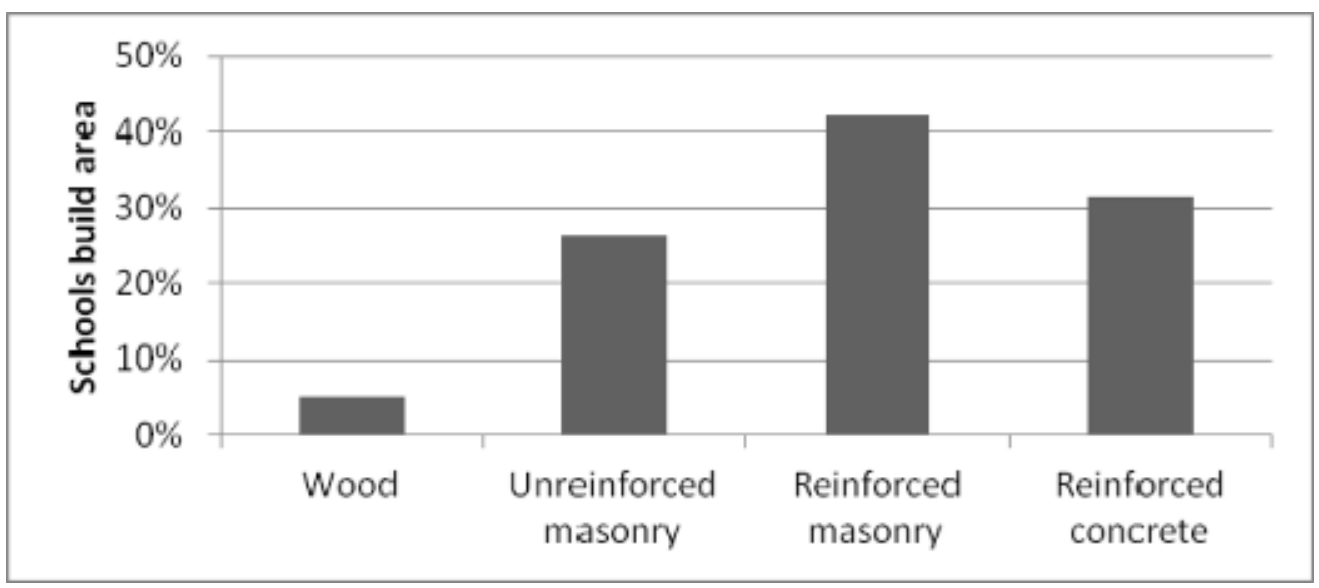

Figure 2. Composition of the built area of the schools by structural typologies

The results of the exposure assessment are summarized in a file which includes: the school built area, the economic value and the number of students at each municipality disaggregated by structural typologies.

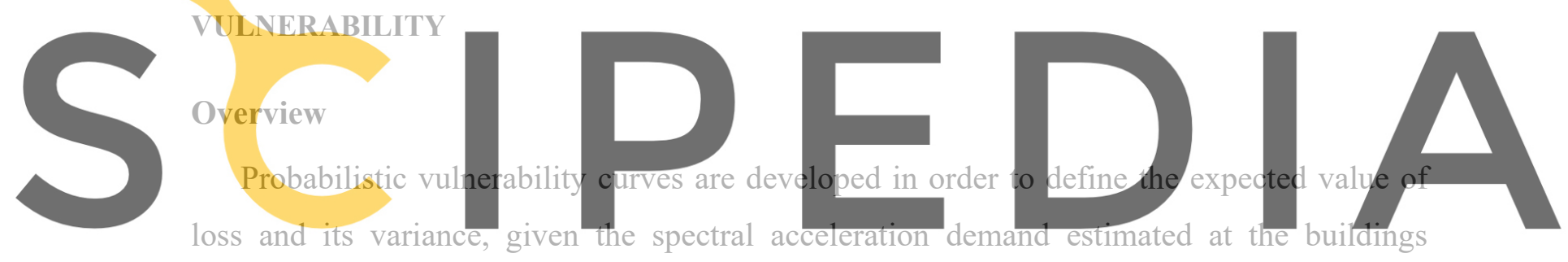

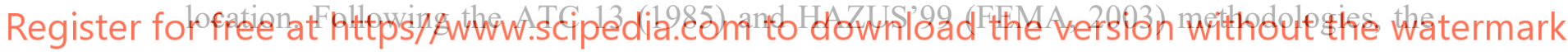

loss is expressed in terms of Mean Damage Ratio, which is the ratio of the structural reparation costs to the reposition value of the building. In addition, the variables considered in the ATC13 and HAZUS methodologies were adapted to the Colombian building code in order to reflect features of the Colombian building practices and, consequently, the capacity of these buildings.

Each of the identified structural typology is characterized by a bilinear capacity spectrum according to the mentioned methodologies with variables fitted to the Colombian environment. Thus, the vulnerability curves are defined as follows: (i) Loss reference levels for the yielding $\left(S d_{y}\right)$ and ultimate displacement $\left(S d_{u}\right)$ of the building are selected. According to the ATC 13 methodology, 5\% and 100\% levels were used, respectively. (ii) The probability distribution of the losses and the expected value and its variance, are defined, given the spectral displacement of the building and the loss reference levels selected in the previous step. 


\section{Expected value of the loss}

The expected value of the loss $\mathrm{E}(\beta)$ is obtained in this article by using the following expression (Miranda, 1999; Ordaz et al, 1998):

$$
\mathrm{E}\left(\beta \mid S d\left(T_{e}\right)\right)=\left(1-\exp \left[\ln \left(1-\beta_{0}\right)\left(\frac{S d\left(T_{e}\right)}{S d_{y}}\right)^{\varepsilon}\right]\right)
$$

where $S d\left(T_{e}\right)$ corresponds to the spectral displacement, $T_{e}$ is the fundamental period of the structural typology, $\beta_{0}$ represents the expected loss associated to the reference spectral displacement $S d y$. Often, $\beta_{0}$ takes the value of $5 \% ; S d y$ is the spectral displacement at the yielding point of the structure in the bilinear capacity spectrum and $\varepsilon$ is a factor that is used in order to fit the curve to the levels of loss defined for the point of ultimate capacity.

Since the seismic action is expressed in terms of the spectral acceleration for a given structural period $S a(T)$, it is necessary to convert those values into spectral displacement

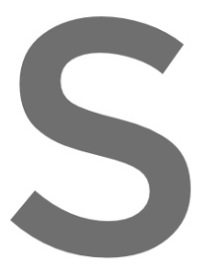
using the following
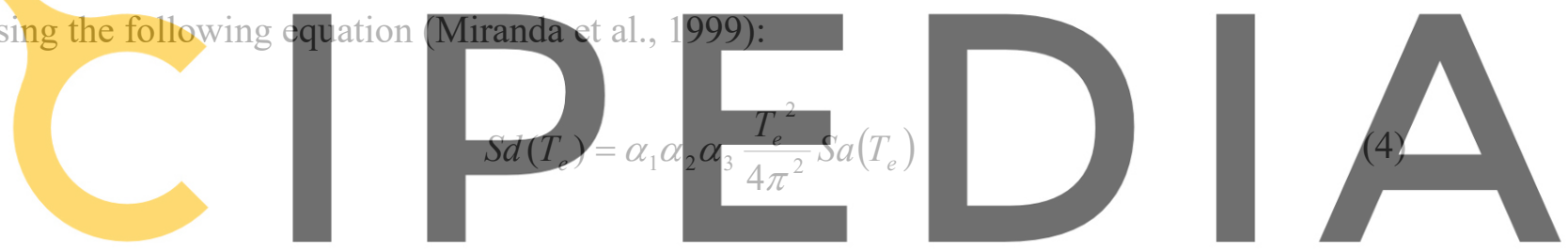

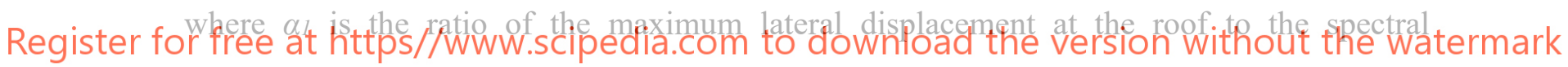
displacement considering an elastic model; $\alpha_{2}$ is the ratio of the maximum interstory drift to

the global drift of the structure, which is defined as the maximum lateral displacement at the roof divided by the height of the structure; and $\alpha_{3}$ is the ratio of the maximum lateral displacement considering an inelastic model to the maximum displacement of the elastic model.

\section{Probability distribution and standard deviation of the loss}

In this article, we considered that the probability of loss, $\beta$, follows a standard beta distribution as in ATC-13 (1985) depending on the ground motion intensity.

$$
\mathrm{P}_{\beta \mid \gamma_{i}}(\beta)=\frac{\Gamma(a+b)}{\Gamma(a) \Gamma(b)} \beta^{a-1}(1-\beta)^{b-1}
$$


The parameters $a$ and $b$ of the distribution are computed from the expected value of the loss, given a specific spectral displacement (see Equation 3) according the following equations: 6 and 7.

$$
\begin{gathered}
a=\frac{1-\mathrm{E}\left(\beta \mid S d\left(T_{e}\right)\right)-\mathrm{E}\left(\beta \mid S d\left(T_{e}\right)\right) \mathrm{C}^{2}(\beta)}{\mathrm{C}^{2}(\beta)} \\
b=a\left[\frac{1-\mathrm{E}\left(\beta \mid S d\left(T_{e}\right)\right)}{\mathrm{E}\left(\beta \mid S d\left(T_{e}\right)\right)}\right]
\end{gathered}
$$

The coefficient of variation of the loss $\mathrm{C}(\beta)$ is calculated as follows:

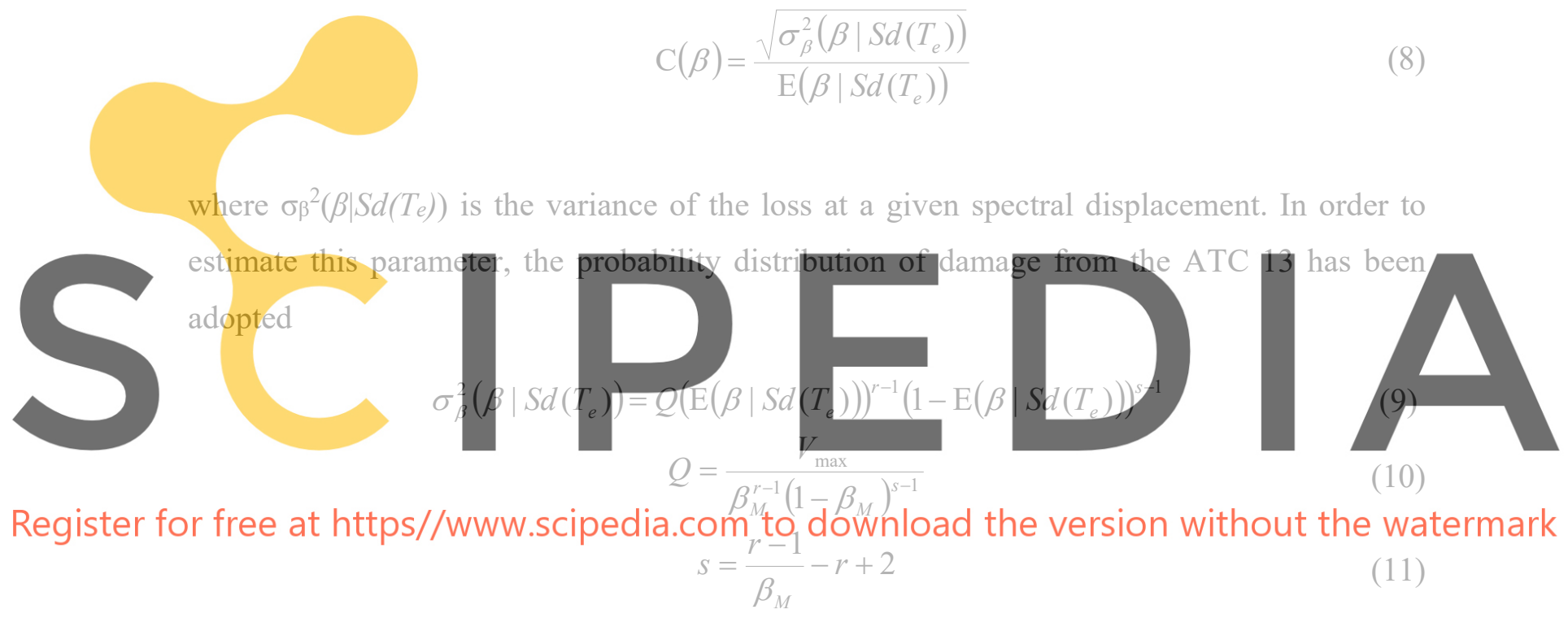

where $V_{\max }$ is the maximum variance of the loss in all range from $0 \%$ to $100 \%, \beta_{M}$ is the loss where the maximum variance occurs and $r$ is a shape factor. In Graf \& Lee (2009), the standard deviation is assumed to be 0.15 for the $50 \%$ of the damage factor. In this work, $V_{\max }$ is assumed to be 0.0625 , whith a standard deviation of $0.25 ; \beta_{M}$ is fixed at the $50 \%$ and $r$ is assumed to be 3. Once established the expected value of the loss and of its variance, it is possible to estimate its probability distribution, given a specific spectral acceleration. As an example, the capacity spectrum of the unreinforced masonry building typology is shown in Figure 3(a) while Figure 3(b) shows the correspondent vulnerability curve (expected damage and variance for certain Seismic demand, $E(\beta \mid S d))$. 

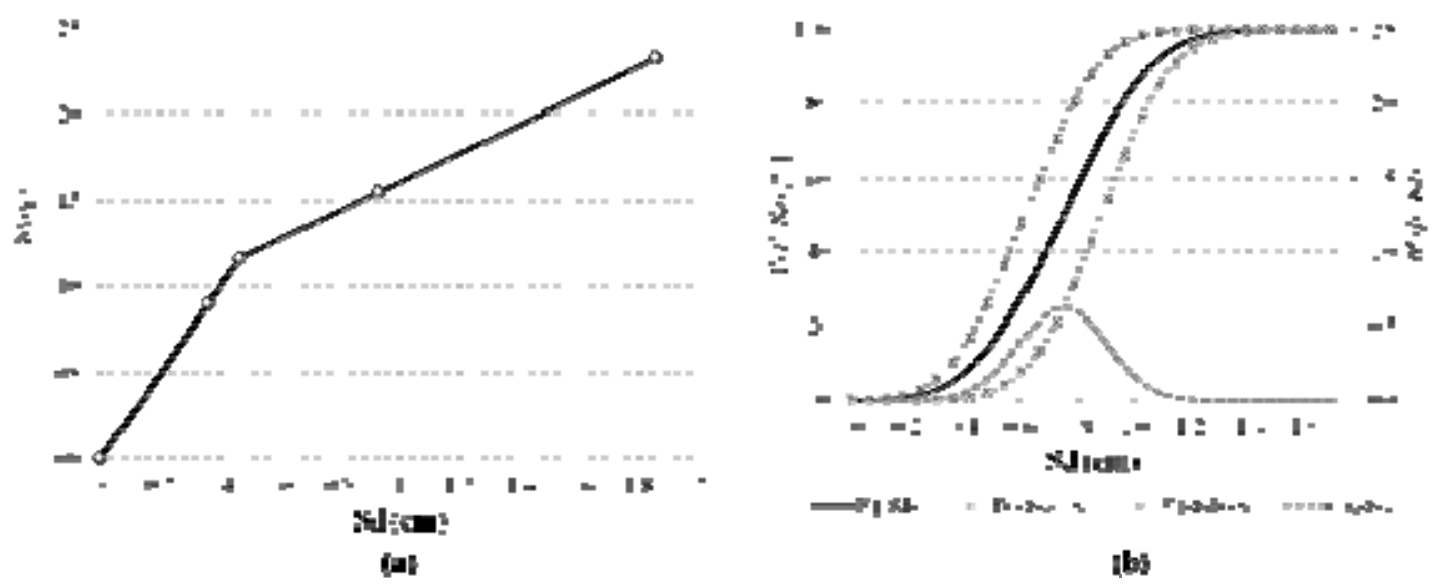

Figure 3. Unreinforced masonry building typology. (a) capacity curve and

(b) vulnerability curve, $\mathrm{E}(\beta \mid \mathrm{Sd})$

\section{Vulnerability characterization of current and retrofitted school building typologies}

School buildings have been characterized in this article by structural typologies and are designed for a specific design code level which varies from pre-code (buildings without code design) to low code and high code; all these levels are related to the capacity standards for seismic strength. The retrofitting or strengthening alternatives considered herein are the following: a) unreinforced masonry buildings are replaced by new facilities of reinforced masonry; this alternative not only improves the seismic safety, but also upgrades the infrastructure. b) For the remaining structural typologies, low-code / high-code capacity spectra have been assumed for the current and retrofitted case, respectively. Additional modifications have been adopted in the ductility and seismic coefficient for these typologies according to the requirements of the Colombian building code NSR-10. The sources of the parameters of the capacity spectra are summarized in Table 3 . The vulnerability curves (expected values) are shown in Figure 4(a) and Figure 4(b) for the current and retrofitted cases, respectively.

Table 3. References of the capacity curves for the current case and the retrofitted

\begin{tabular}{|c|c|c|c|c|}
\hline \multirow{3}{*}{ Structural typology } & \multicolumn{2}{|c|}{ Current case } & \multicolumn{2}{|r|}{ Retrofitted } \\
\hline & \multirow{2}{*}{$\begin{array}{l}\text { Original } \\
\text { source }\end{array}$} & $\begin{array}{l}\text { Adjusted } \\
\text { variables }\end{array}$ & \multirow{2}{*}{$\begin{array}{l}\text { Original } \\
\text { source }\end{array}$} & Adjusted variables \\
\hline & & $T e|C s| \gamma \mid \mu$ & & $T e\left|C s^{*}\right| \gamma \mid \mu$ \\
\hline $\begin{array}{l}\text { Unreinforced masonry } \\
\text { buildings }\end{array}$ & $\begin{array}{c}\text { Hazus MH } \\
2003 \text { (FEMA/ } \\
\text { NIBS, 2003) } \\
\text { Pre code }\end{array}$ & $0.4|0.1| 1.3 \mid 2$ & & $\mathrm{~N} / \mathrm{A}$ \\
\hline
\end{tabular}




\begin{tabular}{|c|c|c|c|c|}
\hline $\begin{array}{l}\text { Reinforced masonry } \\
\text { buildings with concrete } \\
\text { diaphragms }\end{array}$ & \multirow{4}{*}{$\begin{array}{c}\text { Hazus } \\
\text { MH(2003) } \\
\text { (FEMA/ } \\
\text { NIBS, 2003) } \\
\text { Low code }\end{array}$} & N/A & \multirow{4}{*}{$\begin{array}{c}\text { Hazus } \\
\text { MH(2003) } \\
\text { (FEMA/ } \\
\text { NIBS, 2003) } \\
\text { High code }\end{array}$} & $|0.3| 0.20-0.25|1.8| 4$ \\
\hline $\begin{array}{l}\text { Concrete frames with } \\
\text { unreinforced masonry walls }\end{array}$ & & $0.3|0.1| 1.5 \mid 4$ & & $0.4|0.20-0.25| 1.5 \mid 8$ \\
\hline $\begin{array}{l}\text { Precast concrete frames } \\
\text { with concrete shear walls }\end{array}$ & & $0.4|0.1| 1.5 \mid 4$ & & $0.4|0.20-0.25| 1.5 \mid 8$ \\
\hline Wood structures & & \begin{tabular}{|l|l|l|l|}
0.4 & 0.1 & $1.3 \mid$
\end{tabular} & & \begin{tabular}{|l|l|l|}
0.3 & $0.20-0.25 \mid$ & 1.0
\end{tabular} \\
\hline
\end{tabular}

*The seismic coefficient depends on the location.

Figure 4. Vulnerability curves, (a) current case; (b) retrofitted case

\section{RISK}

\section{Loss Exceedance Curve}

The Loss Exceedance Curve (LEC) usually specifies the annual frequencies (also known as the exceedance rate) of the events that exceed a specific loss value. The exceedance rate is obtained according to the following equation:

$$
v(\beta)=\sum_{i=1}^{\text {events }} \mathrm{P}(B>\beta \mid i) f_{A}(i)
$$

where $v(\beta)$ is the exceedance rate of the loss, $\beta$, which is the sum of the losses that may occur in all exposed elements; $f_{A}(\mathrm{i})$ is the annual frequency of the event $i ; \mathrm{P}(B>\beta \mid i)$ is the probability that the loss be greater than $\beta$, given the occurrence of the event $i$. The exceedance rate is then obtained as the sum of all the potential harmful events. The inverse of $v(\beta)$ is the return period of loss.

The sum of the losses that may occur in all the exposed elements due to an event is obtained as the linear combination of random variables, using the method proposed by the National Commission for Insurance of Mexico (CNSF, 2007) to estimate the expected value and the dispersion. A correlation factor between losses from building to building of 0.2 was adopted from a performed simulation and a sensitivity analysis. Wesson et al. (2009) present a methodology in order to estimate the LEC based on the inputs of the seismic hazard analysis. The following procedure to estimate LEC with equation (12) is used in this article: (i) for a given hazard scenario, the probability distribution of the loss is estimated for each municipality and structural typology using the equations (5), (6) and (7); (ii) the probability 
distribution of the losses is estimated for each exposed element and summed to the previous value; (iii) the probability that the total loss for each scenario exceeds a certain value $\beta$ is calculated; (iv) the probability estimated in the previous step is multiplied by the annual frequency of occurrence of the event $i$. This procedure must be repeated for each event $i$ included in the hazard assessment.

\section{Annual Average Loss}

The area under the LEC is known as the Average Annual Loss (AAL). The AAL is the expected value of the annual loss and represents, in a simple insurance scheme, the actuarially fair insurance premium. It is obtained either by integration of the $v(\beta)$ or by using the following equation:

$$
A A L=\sum_{i=1}^{\text {events }} \mathrm{E}(\beta \mid i) f_{A}(i)
$$

In this article, the metrics described above are estimated using the open source software CAPRA GIS $^{1}$ (Cardona et al., 2010).

\section{BENEFIT-COST ANALYSIS}

Retrofitting cost is related to the adopted structural intervention solution in order to guarantee a pre defined level of safety of the structure and it depends on the structural system of the buildings and on their seismic design. For a benchmark on typical retrofitting costs, it is possible to consider the values suggested in FEMA 156 (FEMA, 1994 b) and FEMA 157 (FEMA, 1994 c). Also, rehabilitation costs have been suggested as a 12\% of the buildings value by Kappos \& Dimitrakopoulos (2008).

According to Coca (2006), the average cost of the structural interventions of the schools in Bogotá was about 240 US\$ per $\mathrm{m}^{2}$; the interventions consisted in retrofitting some of the structures and in replacing others, reason for which that value seems high on average. Based on the available information, the retrofitting/replacement costs were assumed as follows: i) unreinforced masonry buildings are replaced by new reinforced masonry buildings, that is, a new construction is built with an investment equal to the replacement value; ii) for the

\footnotetext{
${ }^{1}$ Comprehensive Approach to Probabilistic Risk Assessment, CAPRA - www.ecapra.org. This software was developed with the support of the IADB, the World Bank and the UN-ISDR - International Strategy for Disaster Reduction.
} 
remaining structural typologies, retrofitting costs were considered to be the $15 \%$ of the value of the buildings. It should be noticed here that these constant values are assumed for retrofitting costs not for reparation costs, to bring back the functionality of the building just after a seismic event; herein, retrofitting costs should be considered as investment to reduce future possible losses as a risk reduction strategy. At the same time, retrofitting is assumed to be over all buildings of municipality whit retrofitting criteria exposed on previous vulnerability characterization section.

The discount rate $\tau$ used to convert losses due to future earthquakes into present (monetary) value is $3 \%$. Similar values have been suggested by Kappos \& Dimitrakopoulos (2008) and in the Benefit-Cost Model for the assessment of Seismic Rehabilitation of Federal Buildings (FEMA, 1994 a).

\section{RESULTS}

Figure 5a shows the exposed value and Figure 5b the AAL obtained for the municipalities of Colombia and for the existing state of the buildings. Using the proposed method, the benefit-cost ratio, BCR, has been estimated for each department of Colombia (first order administrative division within the country) and the national education budget allocation. The obtained results are summarized in figures 6 and 7 .

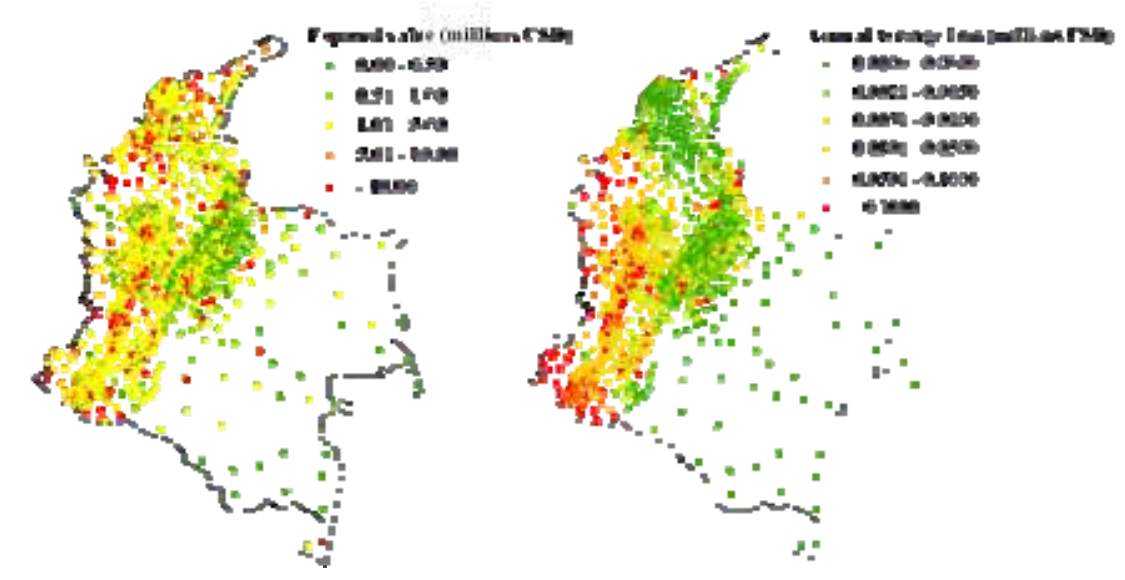

Figure 5 (a) Exposed value; (b) Annual Average Loss for each municipality, for the existing state of the buildings. 


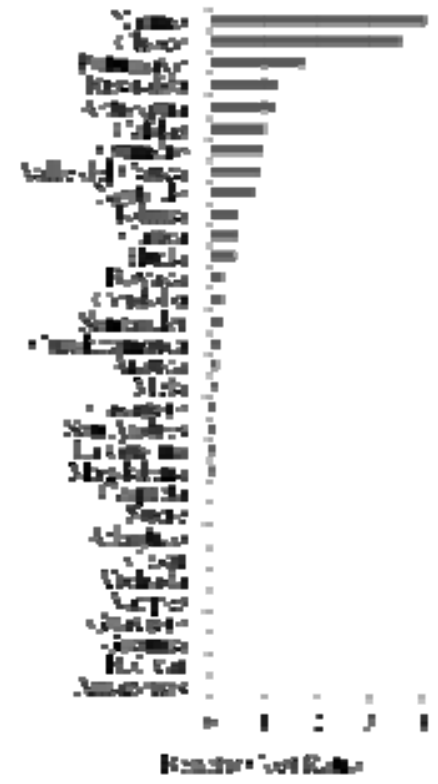

(a)

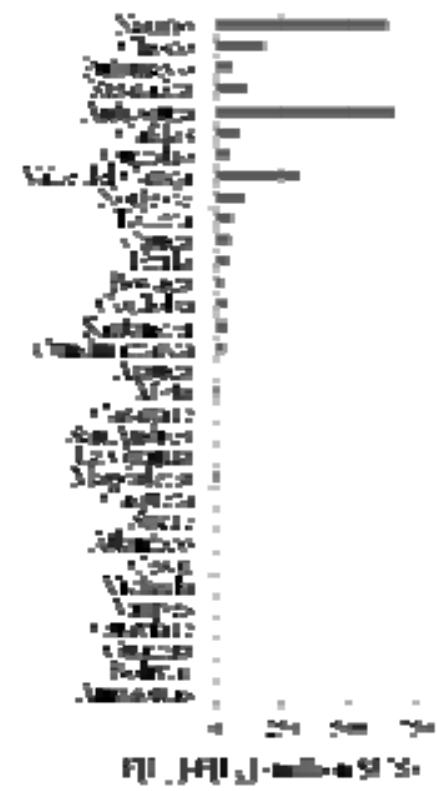

(b)

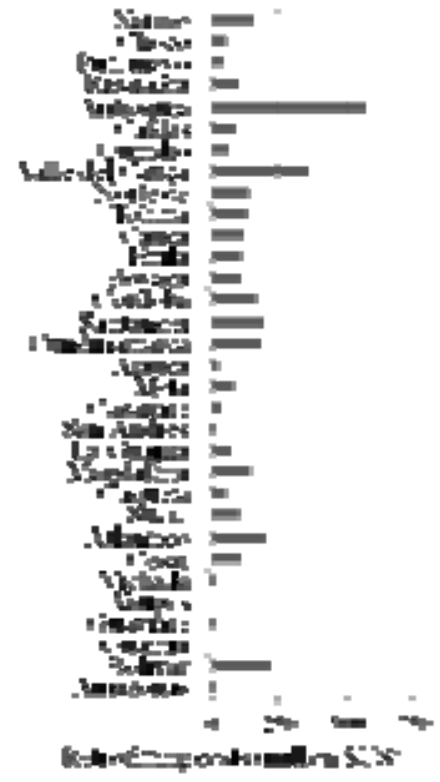

(c)

Figure 6. (a) BCR per Department; (b) Difference between the expected present value of the AAL in the initial, not retrofitted state of the buildings and in the retrofitted case $\left(E\left[\mathrm{~L}_{U}\right]-\mathrm{E}\left[\mathrm{L}_{R}\right]\right) ;(c)$ the retrofitting costs

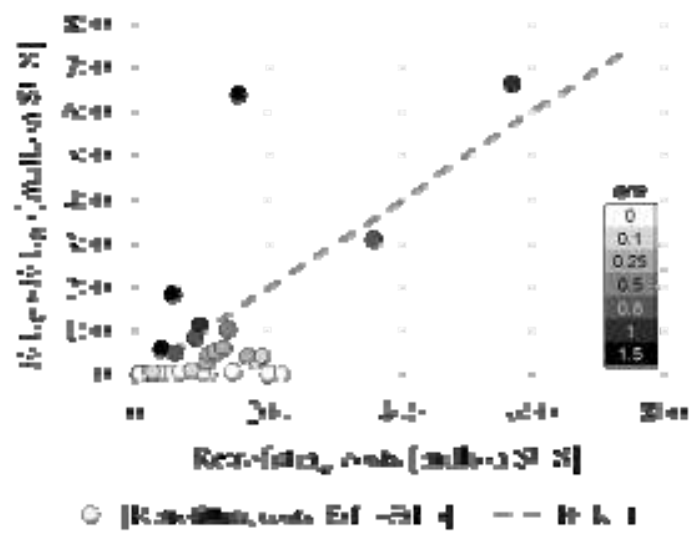

64)

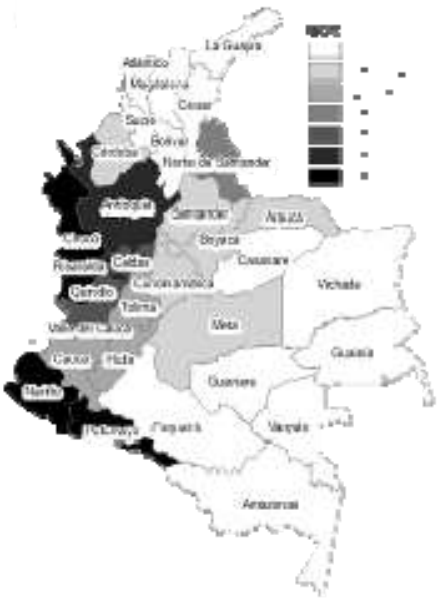

(b)

Figure 7. (a) Difference between the expected value of the AAL in the initial, not retrofitted state of the buildings and in the retrofitted case $\left(E\left[\mathrm{~L}_{U}\right]-\mathrm{E}\left[\mathrm{L}_{\mathrm{R}}\right]\right)$ represented in function of the retrofitting costs;

(b) BCR per department

The differences between the net present value of the AAL (not retrofitted case retrofitted case) are plotted in Figure 7(a) in function of the retrofitting costs. The points above the line corresponding to $\mathrm{BCR}=1$ represent the departments for which, from a financial perspective, better resources allocation in risk knowledge of the schools is feasible. And, from here, technical studies based on reliable information of school buildings can be 
developed, addressed to proper investments to increase schools safety. From figures 1(c), 5 (a), 5(b), 6(a) and 7(b), it is possible to identify that the BCR is higher than 1 in the departments in which the seismic hazard, the concentration of exposed values and the estimated losses are higher in the context of the country. Also, it is observed in figures 6 (a) and 6(b) that in regions of low or moderate seismic hazard, the reduction of the net present value of $A A L(E[L u]-E[L R])$ is not significant when compared to the retrofitting costs. Thus, in those regions, the seismic upgrading of the schools is not profitable. The results shown in Figure 6 represent not only the BCR values obtained from the above analysis but also a prioritization proposal. These results, combined with those of Figure 7, should be used to priorities to the structural interventions.

\section{CONCLUSIONS}

This article proposes a methodology for a preliminary assessment of the feasibility of a hypothetical retrofitting of schools built area and applies it to the case of Colombia. Rough assumptions have been made to estimate the total built area, its economic value and its retrofitting cost, as well as to classify the buildings into structural typologies. Each structural typology is characterized by a specific vulnerability curve that relate the expected value of loss and its variance with the ground motion intensity. The assessment of the annual average loss of public schools built areas is carried out in the initial, non-retrofitted case, and also in the case of an hypothetical structural intervention. The expected losses are aggregated by subnational administrative units in Colombia (departments), taking into account a set of stochastic events generated according to the seismicity of the country. By comparing the loss estimates and the expected costs of the intervention, a benefit/cost ratio, BCR, is obtained. The mentioned departments may be ranked by BCR in order to decide on the feasibility of the structural intervention. It is possible to observe from the case study that the BCR is consistent with the seismic hazard (see figure $7 \mathrm{~b}$ ), the geographical distribution of the exposed values and the loss estimates. The values of the BCR highlight the regions where the structural intervention is more attractive according to the seismic risk, like Nariño, Chocó and Putumayo (see figure 6a). Thus, this methodology is very useful for prioritizing the investments in risk reduction within the framework of a national program as in the cases of Antioquia and Valle del Cauca where the reduction in expected losses is attractive (see figure $6 b)$. 
For example, at national level, the retrofitting costs are estimated in 3,562 millions \$US. Those costs may represent the $30 \%$ of the total annual education investment in Colombia in 2010, which represents a significant financial effort. Without a risk based prioritization criterion, the total investment required at the national level would not be profitable. By using the $\mathrm{BCR}$, it is possible to define a threshold in order to promote the risk knowledge. On this matter, it is possible to define a threshold in order to allocate scarce resources for school safety. This means that, if it is assumed that all the departments with a BCR $>1$ should develop risk knowledge strategies, the expected costs would be around 898 million \$US (this cost includes the first 5 departments of figure $6 \mathrm{c}$ ), which represent the $25 \%$ of the total safety upgrading cost of the country and accumulates the $87 \%$ of the losses reduction at country level(reduction corresponding to the first 5 departments of figure 6b). If the threshold is defined by a BCR $>0.75$, the expected costs would be around 1,529 million \$US, which represent the $43 \%$ of the total safety upgrading cost in the country. These results become an input for the decision process in a comprehensive risk management.

The scope of this methodology is limited to preliminary evaluations, useful only for prioritization procedures. Given the uncertainties, the results cannot be considered as actual and objective measurements and used as inputs into financial analyses. Conversely, it should be noted that the use of the proposed benefit-cost analysis is only valid as an indicative comparison of the economical advantages among alternatives (Doorn \& Hansson, 2010). The sources of uncertainties can be reduced by detailing the information for the buildings characteristics distribution across the country and can be solved by developing a reasonable description of the common schools typologies as shown in Lopez et al. (2007).

An important improvement of the results can come from the inclusion of other variables such as indirect economic losses, to include also the social and political aspects in the decision-making process related to risk reduction programs (Hansson, 2007). In this regard, the use of risk indicators, based on a holistic approach is suggested (Carreño et al., 2012; Barbat et al., 2011; Barbat et al., 2010).

\section{AKNOWLEDGMENT}

The authors express their gratitude to the Florida International University (FIU), particularly to the scholarship "Paul C. Bell, Jr." for risk management, for the financial 
support. They are also grateful to the International Center of Numerical Methods in Engineering (CIMNE) and to the Polytechnic University of Catalonia (UPC) for the support to the developed work. This work has been also partially funded by the Spanish Government, through the research project "Enfoque integral y probabilista para la evaluación del riesgo sísmico en España, CoPASRE" (CGL2011-29063) and by the European Commission through de research project DESURBS-FP7-2011-261652.

\section{REFERENCES}

AIS (2009). Estudio general de amenaza sísmica de Colombia 2009. Asociación Colombiana de Ingeniería Sísmica. Bogotá, Colombia.

Aven, T. \& Kristensen, V. (2005). Perspectives on risk: review and discussion of the basis for establishing a unified and holistic approach. Reliability Engineering and System Safety, 90, 114.

ATC-13 (1985). Earthquake damage evaluation data for California. Applied Technology Council, Redwood City, California, USA.

Barbat, A.H., Pujades, L.G., Lantada, N., \& Moreno, R. (2008). Seismic damage evaluation in urban areas using the capacity spectrum method: application to Barcelona, Soil Dynamics and Earthquake Engineering, 28, 851-865.

Barbat, A.H., Carreño, M.L., Pujades, L.G, Lantada, N., Cardona, O.D., \& Marulanda, M.C. (2010). Seismic vulnerability and risk evaluation methods for urban areas. A review with application to a pilot area, Structure and Infrastructure Engineering, 6(12) 17-38.

Barbat, A.H., Carreño, M.L., Cardona, O.D., \& Marulanda, M.C. (2011) Evaluación holística del riesgo sísmico en zonas urbanas, Revista internacional de métodos numéricos para cálculo y diseño en ingeniería, 27(1), 3-27.

Birkmann, J., Cardona, O. D., Carreño, M. L., Barbat, A. H., Pelling, M., Schneiderbauer, S., Kienberger S., Keiler, M., Zeil, P., and Torsten Welle. (2013). Framing vulnerability, risk and societal responses: the MOVE framework", Natural Hazards 67(2) 193-211.

Cardona, O. D., Ordaz, M. G., Reinoso, E., Yamin, L. E., \& Barbat, A. H. (2010). Comprehensive approach for probabilistic risk assessment (CAPRA): International Initiative for disaster risk management effectiveness. Presented at the 14th ECEE, Ohrid, Macedonia. 
Carreño, M.L., Cardona, O.D., \& Barbat, A.H. (2012). Holistic evaluation of the seismic urban risk using the fuzzy sets theory. Bulletin of Earthquake Engineering, 10(2), 547565 .

CEPAL. (1999). El Terremoto de enero de 1999 en Colombia: Impacto socioeconómico del desastre en la zona del Eje Cafetero. Comisión Económica Para América Latina y el Caribe. Available at http://www.eclac.cl/dmaah/mdn/cd/evaluaciones/t_e_1999.pdf [Last checked 20/03/2012].

CNSF. (2007). Mediante la cual se dan a conocer a las instituciones de seguros las bases técnicas que se deberán utilizar para el cálculo de la Pérdida Máxima Probable de los seguros de huracán y/u otros riesgos hidrometeorológicos (Circular No. S-10.4.1.1). México: Secretaría de Hacienda y Crédito Público - Comisión Nacional de Seguros y Fianzas.

Coca, C. (2006). Risk management and sustainability in educative sector experience of Bogota, Colombia. Available at:

http://www.preventionweb.net/english/professional/trainings-events/edumaterials/v.php?id=7673 $>$ [Last checked 25/04/2010].

Coca, C. (2011). Reducción del riesgo sísmico y sostenibilidad urbana. Un caso en el sector educativo de Bogotá. Editorial: Universidad Nacional de Colombia (Sede Bogotá). Instituto de Estudios Ambientales, IDEA. ISBN: 9789587196443.

Crowley, H. \& Bommer, J.J. (2006). Modelling Seismic Hazard in Earthquake Loss Models with Spatially Distributed Exposure. Bulletin of Earthquake Engineering 4(3) 249-273

DANE (2008). Número de alumnos matriculados por nivel educativo y sector. Colombia. Available at:

http://www.dane.gov.co/index.php?option $=$ com_content\&view $=$ article\&id=108\&Itemid $=58$ [Last checked 23/02/2012].

Doorn, N. \& Hansson, S.O (2010) Should Probabilistic Design Replace Safety Factors. Philosophy Technology. 24(2), 151-168.

Egozcue, J. J., Barbat, A. H., Canas, J. A., Miquel, J. and Banda, E. (1991), A method to estimate occurrence probabilities in low seismic activity regions. Earthquake Engineering and Structural Dynamics 20(1) 43-60.

FEMA. (1994 a). Seismic Rehabilitation of Federal Buildings: A Benefit/Cost Model. Volume 2 - Supporting Documentation. (FEMA-256 I) Sept 1994 Prepared for the 
Federal Emergency Management Agency Under Contract No. EMW-92-6-3976 by VSP Associates, Inc. 455 University Avenue, Suite 340 Sacramento, CA 95825 June 30, 1994.

FEMA. (1994 b). Typical costs for seismic rehabilitation of existing buildings (FEMA 156). Second edition. Earthquake hazards reduction series 39. Issued by FEMA in furtherance of the Decade for Natural Disaster Reduction. Earthquake hazards reduction series 39. Issued by FEMA in furtherance of the Decade for Natural Disaster Reduction. Available at: http://www.fema.gov/library/viewRecord.do?id=1630 [Last checked 22/03/2012].

FEMA. (1994c). Typical Costs for Seismic Rehabilitation of Existing Buildings. Second edition. Volume 2 -Supporting Documentation. (FEMA 157). Available at: http://www.fema.gov/library/viewRecord.do?id=1631 [Last checked 22/03/2012].

FEMA/NIBS. (2003). Multi-hazard Loss Estimation Methodology. Earthquake Model HAZUS $® M H$ MR4 Technical Manual. Department of Homeland Security, Emergency Preparedness and Response Directorate, Mitigation Division and National Institute of Building Sciences Washington, D.C. Available at:

$<$ http://www.fema.gov/plan/prevent/hazus/hz_manuals.shtm $>$ [Last checked 11/02/2010].

Gallego, M. (1999). Estimación del riesgo sísmico en la república de Colombia, Tesis de Maestría, División de Estudios de Posgrado, UNAM.

GAR. (2011). Global Assessment Report on Disaster Risk Reduction 2011. Revealing Risk, Redefining Development. Available at: http://www.preventionweb.net/english/hyogo/gar/2011/en/bgdocs/GAR2011/GAR2011_Report_Chapter5.pdf. [Last checked 11/07/2011].

Graf, W.P. \& Lee, Y. (2009). Code-Oriented Damage Assessment for Buildings. Earthquake Spectra, 25(1) 17-37.

Grant, D.N., Bommer, J.J., Pinho, R., Calvi, G.M., Goretti, A. \& Meroni, F. (2007). A prioritization scheme for seismic intervention in school buildings in Italy. Earthquake Spectra 23(2) 291-314.

Grossi, P. (2008) Modeling Seismic Mitigation Strategies. Risk Assessment, Modeling and Decision Support, 227-245.

GTC 223 (2011) Guide for the preparation of school infrastructure plans. Edited by the Instituto Colombiano de Normas Técnicas y Certificación (ICONTEC). [On line]. 
Available at: http://www.mineducacion.gov.co/1621/articles-296985_archivo_pdf.pdf. [Last checked 22/03/2012].

Hadjian, A. (2002). A general framework for risk-consistent seismic design. Earthquake engineering and structural dynamics 31, 601-626.

Hansson, S.O. (2007). Philosophical problems in cost-benefit analysis. Economics and Philosophy, 23 163-183.

Kappos, A.J. \& Dimitrakopoulos, E.G. (2008). Feasibility of pre-earthquake strengthening of buildings based on cost-benefit and life-cycle cost analysis, with the aid of fragility curves. Natural Hazards 45(1), 33-54.

Lantada, N., Pujades, L.G., \& Barbat, A.H. (2009). Vulnerability index and capacity spectrum based methods for urban seismic risk evaluation. A comparison. Natural Hazards, 51, 501-524.

López, O.A., Hernandez, J.J., Del Re, G., Puig, J., \& Espinosa, L. (2007). Reducing seismic risk of schools in Venezuela. Earthquake Spectra. 23(4) 771-790.

López O.A., Hernandez, J.J., Marinilli A., Bonilla R., Fernandez N., Dominguez J., Baloa T., Coronel G., \& Safina S. (2008). Seismic Evaluation and Retrofit of School Buildings in Venezuela. The 14th World Conference on Earthquake Engineering, October 12-17, 2008, Beijing, China. Paper ID 09-01-0041.

Maldonado, R. (1999). Historia de la arquitectura escolar en Colombia. Editorial: Universidad Nacional de Colombia (Sede Bogotá). ISBN: 958-8051-61-4.

May P.J. (2007). Societal Implications of Performance-Based Earthquake Engineering. PEER Report 2006/12 Pacific Earthquake Engineering Research Center College of Engineering University of California, Berkeley.

Miranda, E. (1999). Approximate seismic lateral deformation demands on multistory buildings. Journal of Structural Engineering 125(4), 417-425.

Mora, M.G., Ordaz, M., Yamin, L.E., \& Cardona, O.D. (2011). Relaciones beneficio costo probabilistas de rehabilitación sísmica, Cuarto Congreso Nacional de Ingeniería Sísmica, Granada, Spain, 18-20 de mayo de 2011. Paper ID 60.

NSR-98 (1998). Normas Colombianas De Diseño y Construcción Sismo Resistente NSR-98. Asociación Colombiana de Ingeniería Sísmica. Bogotá, D. C., Colombia. 
NSR-10 (2010). Reglamento Colombiano De Construcción Sismo Resistente NSR-10. Asociación Colombiana de Ingeniería Sísmica. Bogotá, D. C., Colombia.

Ordaz, M., Miranda, E., Reinoso, E., \& Pérez-Rocha, L.E. (1998). Seismic Loss Estimation Model for México City. 12 World Conference on Earthquake Engineering. Auckland, New Zealand, 30 January - Friday 4 February 2000 Paper No 1902.

Ordaz, M., Aguilar, A., \& Arboleda, J. ( 2007). CRISIS 2007. Program for computing seismic hazard. (Version 7.2). Instituto de Ingeniería. Universidad Nacional Autónoma de México. Available at:

$<$ http://ecapra.org/capra_wiki/en_wiki/index.php?title=CRISIS2007>.

Proyectos y Diseños -P\&D. (2000). Evaluación preliminar de vulnerabilidad sísmica centros educativos distritales. Secretaria De Educación Distrito Capital De Santafé De Bogotá. Bogotá, Colombia.

SED - Secretaría de Educación del Distrito Capital. (2004). REFORZAMIENTO ESTRUCTURAL SED.xls. [Excel workbook].

Silva, V., Crowley, H., Pagani, M., Monelli, D., \& Pinho, R. (2013). Development of the OpenQuake engine, the Global Earthquake Model's open-source software for seismic risk assessment. Natural Hazards. DOI 10.1007/s11069-013-0618-x.

Smyth, A.W., Altay, G., Deodatis, G., Erdick, M., Franco, G., Gülkan, P., Kunreuther, H., Luş, H., Mete, E., Seeber, N., \& Yüzügüllü, Ö. (2004a). Probabilistic Benefit-Cost Analysis for Earthquake Damage Mitigation: Evaluating Measures for Apartment Houses in Turkey. Earthquake Spectra 20, 171-203.

Smyth, A.W., Deodatis, G., Franco, G., He, Y., \& Gurvich, T. (2004b). Evaluating earthquake retrofitting measures for schools: a cost-benefit analysis. Keeping Schools Safe in Earthquakes. Proceedings of the ad hoc Experts' Group Meeting on Earthquake Safety in Schools, Paris, 9 to 11 February 2004. Available at:

$<\mathrm{http}: / / w w w . o e c d . o r g / d o c u m e n t / 61 / 0,3746$, en_2649_39263294_34748797_1_1_1_1,00. html $>$ [Last checked 23/02/2012].

Valcárcel, J. A., Mora, M. G., Cardona, O. D., Pujades, L. G., Barbat, A. H., \& Bernal, G. A. (2013). Methodology and applications for the benefit cost analysis of the seismic risk reduction in building portfolios at broadscale. Natural Hazards. DOI 10.1007/s11069013-0739-2. 
Wesson, R. L., Perkins, D. M., Luco, N., \& Karaca, E. (2009). Direct Calculation of the Probability Distribution for Earthquake Losses to a Portfolio. Earthquake Spectra, 25(3), 687-706.

World Bank. (2011). World Development Indicators (p. 460). Washington, D.C.: World Bank.

Yakut, A., Tonguç, A., \& Gülkan P. (2008). A comparative seismic performance assessment and rehabilitation of existing school buildings. 14th World Conference on Earthquake Engineering, October 12-17, 2008, Beijing, China. 